\title{
Elegance and excesses: War, Gold and Borrowings: New Zealand Architecture in the 1860s
}

\section{Christine McCarthy}

The 1860s were an eventful time for architecture in New Zealand. On the eve of the decade, in 1859, William Mason became the first person to be a registered architect in New Zealand. ${ }^{1}$ The scene was thus set for the English idea of architecture as a profession to more substantially impact on our land. From the decade's beginning were the start of civil wars and the discovery of gold, with New Zealand's first major gold rush in Otago. ${ }^{2}$ It was war and gold which crudely distinguished the decade's histories of the North Island and South Islands. As Salmond notes:

It is no accident that the events which marked the beginning of this period in New Zealand were the gold rushes of the 1860s and the land wars. As Maoris [sic] became less willingly to sell their land, European settlers took large areas by occupation or by force, and in the towns traditional Maori houses were banned by law. Many of the settlers who arrived in the 1860s came in search of gold, and as the European population expanded (from 26,000 in 1850 to 80,000 in 1860, and 100,000 a year later), more houses were needed on more land, and more timber was needed for their

${ }^{1}$ Knight \& Wales Buildings of Dunedin p 25.

${ }^{2}$ Keith \& McRobie Historical Dictionary of New Zealand $\mathrm{p}$ 4. construction. ${ }^{3}$

The population of New Zealand in 1858 was 115,461. By 1874 it was 344,985 . The change in population was not only one of increase. This was the decade when the ratio of Māori:Pākehā population shifted such that Pākehā settlers outnumbered Māori ${ }^{4}$ and no doubt encouraged an increasing sense of Pākehā entitlement. This shift in population, added to the state of New Zealand's existing Pākehā architecture. One of the most important shifts in the decade though, must have been the shift of the colony's capital from Auckland to Wellington in $1865 .^{5}$

The civil wars began in Taranaki, ${ }^{6}$ moved to the Waikato, and by mid-decade had spread to the East Coast. The concentration of war in the North Island was not a co-incidence. Smith describes settlement aspirations as

${ }^{3}$ Salmond Old New Zealand Houses p 89. See also Brown Māori Architecture p 55.

${ }^{4}$ Smith A Concise History of New Zealand p 70.

${ }^{5}$ Keith \& McRobie Historical Dictionary of New Zealand $\mathrm{p}$ 5.

${ }^{6}$ McLean 100 Historic Places in New Zealand p 69 important drivers:

By 1861 the government had purchased two-thirds of New Zealand, mainly in the South Island, where Grey acquired huge tracts such as by the Kemp purchase in 1848 ... By contrast the government had alienated less than a quarter of the North Island by 1861, thwarting government and settler aspirations. Frustrated, in 1860 Governor Thomas Gore Browne sent in imperial troops to enforce the claim to a disputed purchase of land at Waitara in Taranaki, long coverted by settlers. The claim contravened the rights of a majority of owners ... and in doing so fired the opening round in the New Zealand wars of the 1860 s. $^{7}$

The resulting loss of land for Māori caused Te Whiti-o-Rongomai and Tohu Kākahi with others to move to Parihaka in c1866. As Brown describes it:

Here they established a self-sufficient religious community, which was purposefully isolated from Pākehā influence. The law of the Hebrews ... was evident in the community's architecture. Parihaka was confiscated land, and its settlement was seen as an act of defiance by the government. However, Te Whiti and Tohu believed that they had ancestral, political and Christian claims to this land. The consequential crosscultural conflict that developed was expressed through Parihaka's architectural construction, destruction and

7 Smith A Concise History of New Zealand p 68. 
revival. ${ }^{8}$

Gore Browne's "bungling" of this first Taranaki war resulted in the British government bringing George Grey from Cape Town to replace him. ${ }^{9}$ Grey was more aggressive and used more explicitly architectural means to support his attack, building the Great South Road to Hamilton to convey military troops. ${ }^{10}$ Architecture was not simply used asymmetrically in New Zealand's civil warfare. Māori revived and developed the modern pā, first designed and used in the 1840s by Te Ruki Kawiti at Ōhaeawai and Ruapekapeka. ${ }^{11}$ The battle was fought on the land and over the land, in the legislative chamber, as much as in the battle landscape. The New Zealand Settlements Act 1863 , for example, was passed. It allowed the government to confiscate 1.2 million acres from Kingitanga for "public purposes," which effected the more colonial settlement in the North Island. ${ }^{12}$ In 1865 the Native Land Court was established, renamed at the time the "land-taking court."13 It was not only land

${ }^{8}$ Brown Māori Architecture p 71.

${ }^{9}$ Smith A Concise History of New Zealand $\mathrm{p} 71$.

${ }^{10}$ Smith A Concise History of New Zealand p 71.

11 "Ohaeawai - Northern War" n.p.

${ }^{12}$ Smith A Concise History of New Zealand p 72.

${ }^{13}$ Smith A Concise History of New Zealand p 73. which was confiscated, in 1867 Te-Hau-kiTūranga (1840s) was taken and now resides in the National Museum. ${ }^{14}$

The war moved to Tauranga and the wider East Coast, its most famous battle occurring at Gate Pā (Pukehinahina) in 1864, before moving back to Taranaki. This period of fighting involved the followers of Pai Mārire or Hauhau. As in other parts of the country the fighting significantly changed the sociopolitical landscape many Māori lived in. Architectural innovation operated in parallel to support change, most explicitly apparent in Te Kooti Arikirangi Te Tūruki's development of the wharenui, which Brown locates as continuing "a practice of building begun by other East Coast tohunga whakairo." ${ }^{15} \mathrm{Te}$ Kooti, the founder of Ringatū, was exiled to the Chatham Islands in 1865, but he escaped, returning to mainland New Zealand in 1868, the year George Grey had been dismissed as Governor and retired to his Kawau Island mansion, which had been enlarged by designs by Frederick Thatcher. ${ }^{16}$ Over 40 Ringatū meeting houses were built between 1869-1908,

\footnotetext{
${ }^{14}$ Brown Māori Architecture p 49.

${ }^{15}$ Brown Māori Architecture p 58.

${ }^{16}$ Keith \& McRobie Historical Dictionary of New Zealand p 6; England "The Story of Mansion House" p 70.
}

which were "significantly greater than earlier Māori buildings and often equalled the proportions of Christian churches. Not only were the Ringatū meeting houses large enough to walk around inside, they were also able to accommodate Te Kooti's religious services, which were based on those performed by the Anglican Church."17 Roger Neich described the radical changes in meeting house size as follows:

The evidence collected here from Land Court records and from the histories of known houses demonstrates that major changes in house size, function and amount of ornamentation began around Rotoiti and Maketu during the 1860s. Possibly the years of wars, first with Ngapuhi, Waikato and Tauranga, and then the New Zealand Wars, inhibited the full development of the meeting house until this later date. All of the whare whakairo-type meeting houses constructed by Ngati Tarawhai date from after the later 1860s, with a major increase in the 1870s. This was the period when the wars were coming to a close, a period of intense political and religious activity and realignment. The new large meeting houses were built to accommodate meetings discussing land and land sales, political meetings, tribal committees of all sorts, religious meetings, and to provide sleeping accommodation for the guests who travelled to these meetings. The carved and decorated house simply known as Whare Manuhiri, built at Te Taheke in the 1860 s by Ngati Hinerangi as an accommodation house for visitors, including travelling

\footnotetext{
${ }_{17}$ Brown Māori Architecture pp 59-60.
} 
Europeans, was probably an important development in the evolution of the modern meeting house in the Rotorua area. Thus the new meeting house incorporated the functions of the chief's house, the guest house and the church under one roof. ${ }^{18}$

Equally significant was the innovation of polychromatic carving and figurative painting characteristic of these houses. ${ }^{19}$

Meanwhile in the South Island Gabriel Read's discovery of gold at Waitehuna in 1861 initiated the Otago rush. ${ }^{20} 1864$ was the beginning of the discovery of gold in the West Coast. ${ }^{21}$ The migration of people from Otago, Canterbury and Australia to the West Coast inflated the urban scale of towns such as Hokitika and Greymouth. By 1865 more than 40,000 people lived on the West Coast. ${ }^{22}$ According to Hodgson, nearly half of Otago's population lived on the goldfields. ${ }^{23}$ Many Chinese immigrated too, mainly from Canton. $^{24}$ Known as "Celestials," they were initially recruited by provincial governments

${ }_{18}$ Neich Carved Histories p 174.

${ }^{19}$ Brown, Deidre Maori Architecture p 58.

${ }^{20}$ McLean 100 Historic Places in New Zealand pp 70-71.

${ }^{21}$ Keith \& McRobie Historical Dictionary of New Zealand $\mathrm{p}$ 5.

22 Fowler \& van de Voort The New Zealand House p 119.

${ }^{23}$ Hodgson Looking at the Architecture of New Zealand $\mathrm{p} 8$.

${ }^{24}$ Fowler Buildings of New Zealanders p 10. in the mid-1860s and they established several settlements, one of the best known being in Arrowtown. ${ }^{25}$ Before the end of the decade oil would be discovered in Taranaki (in 1866), and gold in the Coromandel peninsular, a year later. ${ }^{26}$

These events resulted in population movements across the country and influenced the architecture built at this time. They also drew commence and money to specific colonial centres. The Otago gold rush brought money to Dunedin and the troops imported for the New Zealand wars brought money to Auckland. These two events caused, what Stacpoole and Beaven have described as, "the first real flowering of architecture in Auckland and Dunedin."27 Stacpoole and Beaven were more explicit about the changing architectural cityscape when they noted that:

Auckland's early wooden buildings, dating from the 1840s, were badly in need of replacement by the midsixties when the town, deprived of its status as capital yet enjoyed a building boom which was made possible by the influx of money brought by the Imperial troops engaged in fighting in the Waikato. To this period

\footnotetext{
${ }^{25}$ McLean 100 Historic Places in New Zealand p 83.

${ }^{26}$ Keith \& McRobie Historical Dictionary of New Zealand p

5.

${ }^{27}$ Stacpoole \& Beaven New Zealand Art p 11.
}

belong the Supreme Court ... by Edward Rumsey ... the coolly classical Bank of New Zealand ... and James Wrigley's Mental Hospital at Avondale ... There were also many hotels, commercial buildings, and private houses of considerable quality and substance. ${ }^{28}$

Likewise, refering to the south of New Zealand, Knight and Wales note that: "The prosperity of the 1860s led to the appreciation of a quality of elegance that the pioneers of the previous decade had not been aware of."29 Smaller towns also grew in their architectural pretensions. Peter Shaw refers to Shrimski and Moss' drapery as the first business premises in Oamaru in Oamaru stone. Built in 1863 it was described as: "the first building in the town with any pretension to architectural style." 30 Later that same year the William Mason-designed Traill and Roxby premises were also built in stone. ${ }^{31}$

Retail architecture appears to have flowered during the decade. In Dunedin, the Arcade, built in 1861 by Henry Farley, was "a popular shopping mall and later known as Broadway until demolished ... There were 40 shops in the

\footnotetext{
${ }^{28}$ Stacpoole \& Beaven New Zealand Art pp 11-12.

${ }^{29}$ Knight \& Wales Buildings of Dunedin p 35.

${ }^{30}$ Shaw Whitestone Oamaru p 10.

${ }^{31}$ Shaw Whitestone Oamaru pp 8-9.
} 
Arcade in 1869."32 In the same city, an elegant corner shops on Manse and Princes Streets built in 1864, have been described by Stacpoole and Beaven as "a fine piece of cabinet-making ... built with the extreme delicacy characteristic of the early Victorian period." ${ }^{33}$ Their architect is unknown.

In Invercargill Burgoyne and Sons General Merchant Iron Store was built in 1864, standing on the current site of the railway hotel. ${ }^{34}$ Kirkcaldie and Stains was founded in $1864,{ }^{35}$ its Toxward-designed building dating from 1868, ${ }^{36}$ and in 1867 Mary Jane and Charlotte Milne opened the millinery and drapery which would later become Milne \& Choyce. ${ }^{37}$ Less permanent structures though housed many other shops. Around Wansbeck Street in Oamaru: in "the main entry to the

${ }^{32}$ Knight \& Wales Buildings of Dunedin p 18.

${ }^{33}$ Stacpoole \& Beaven New Zealand Art p 21, pl. 9.

${ }^{34}$ Dear The Invercargill Book p 52.

${ }^{35}$ Fowler Buildings of New Zealanders p 14.

${ }^{36}$ Kernohan Wellington's Old Buildings p 22.

37 "Department stores and shopping malls: The rise of department stores" n.p.; These were followed the establishment of Dunstable House (now Ballantynes) (1854), and were prior to Smith and Caughey's (1880), DIC (the Drapery and General Importing Company of New Zealand Ltd) (1884), Arthur Barnett's (1903) and Laidlaw Leeds (now Farmers) (1909). town from the south, drapers, grocers, an ironmonger, tailor and clothier, all set up in 1863 premises constructed in the wood and iron of so many colonial towns."38

From the gold rush emerged a larger banking sector. The Bank of New Zealand (BNZ) was founded in 1861, Post Office Savings Bank was formed in 1865, and the Government Life Insurance Office established in 1869.39 Such financial infrastructure required to be housed and buildings to demonstrate the significance of these institutions in the colony. By 1862, the BNZ had 12 New Zealand branches and one in London. ${ }^{40}$ Stone was a preferred material for banks, with Oamaru's Oamaru stone BNZ building dating from $1865,{ }^{41}$ while Auckland's Queen Street branch used Tasmanian sandstone and dates from 1865-67 (designed by Melbourne architect Leonard Terry; supervised by Richard Keals). ${ }^{42}$ Bond

38 Shaw Whitestone Oamaru p 10.

${ }^{39}$ Hodgson Looking at the Architecture of New Zealand $\mathrm{p}$ 10; Keith \& McRobie Historical Dictionary of New Zealand pp 5,6.

${ }^{40}$ Hodgson Looking at the Architecture of New Zealand $\mathrm{p}$ 10.

${ }^{41}$ Shaw Whitestone Oamaru p 10.

${ }^{42}$ McLean 100 Historic Places in New Zealand p 80;

Hodgson Looking at the Architecture of New Zealand p 10; Stacpoole \& Beaven New Zealand Art p 32, pl. 20; Shaw stores were also built, Edinburgh House designed by William Clayton, and built in 1864-65, was later known as McCallum, Neill and Company's Universal Bond. ${ }^{43}$ Dunedin's post office (1864-67; now demolished), with "Italian and Grecian features"44 was designed by William Mason "in the Palladian style,"45 and constructed by Dalrymple \& Co. of Melbourne, ${ }^{46}$ and Oamaru's post office was designed by William Clayton (of Mason and Clayton) in 1864. ${ }^{47}$ Dunedin's post office, which was the first large building built from the newly opened Oamaru quarries, would never be used as a post office. After "being used for a bazaar, a ball and a flower show,"48 it started life as a museum, then the university and finally housed the Stock Exchange. ${ }^{49}$ The establishment of the Post Office Savings Bank however coincided with the beginnings of a worldwide depression which would last until

New Zealand Architecture p 34; "Towering Inferno" pp 137-139.

${ }^{43}$ Knight \& Wales Buildings of Dunedin p 101; Stacpoole \& Beaven New Zealand Art p 11.

${ }^{44}$ Stacpoole William Mason p 85.

${ }^{45}$ Fowler Buildings of New Zealanders p 84

${ }^{46}$ Hodgson Looking at the Architecture of New Zealand $\mathrm{p} 9$. ${ }^{47}$ Martin Built for Us p 12; Shaw Whitestone Oamaru p 11. 48 Stacpoole William Mason p 85.

${ }^{49}$ Stacpoole \& Beaven New Zealand Art p 26, pl 14. 
the mid-1890s. ${ }^{50}$

An emerging educational infrastructure was also evident. The University of New Zealand was founded in 1869, and first opened in Mason's Dunedin Post Office building in 1871.51 The first stage of Wellington College was built in 1868,52 and much of Ben Mountfort's design of Christ's College of 1857 came to fruition in the 1860s..$^{53} \mathrm{JE}$ Fitzgerald's Big School (1863) and Robert Speechly's Chapel (1867), also buildings for Christ's College, were also built during the decade. ${ }^{54}$ Dunedin 1862 saw progress being made in the building of the High School, North Dunedin School, and Green Island School. ${ }^{55}$ In addition, "[d]esigns were made for a stone school at Caversham and a school master's house at North Dunedin."56 Soon after (1864) Lawson designed Park's School in William St. ${ }^{57}$ In 1865, the schoolroom which would

${ }^{50}$ Keith \& McRobie Historical Dictionary of New Zealand $\mathrm{p}$ 5.

${ }^{51}$ Keith \& McRobie Historical Dictionary of New Zealand $\mathrm{p}$

6; Fowler Buildings of New Zealanders p 63.

${ }^{52}$ Kernohan Wellington's Old Buildings p 22.

${ }^{53}$ Hodgson Looking at the Architecture of New Zealand $\mathrm{p} 8$.

${ }^{54}$ Fowler Buildings of New Zealanders p 57.

${ }^{55}$ Knight \& Wales Buildings of Dunedin $\mathrm{p} 34$.

${ }^{56}$ Knight \& Wales Buildings of Dunedin $\mathrm{p} 34$.

${ }^{57}$ Knight \& Wales Buildings of Dunedin pp 127-129. later become Matawhero Church (Presbyterian) in Gisborne, was built. ${ }^{58}$

The increases in population no doubt also caused increases in the number of hotels in New Zealand. In 1866 there were 33 hostelries in Lambton Quay. ${ }^{59}$ The first Thistle Inn was built in 1866.60 Further south, on the west coast (in Ōkārito) the Club Hotel was built (c1866) with now historic concrete foundations, ${ }^{61}$ in Oamaru RA Lawson designed the Star and Garter Hotel (Itchen Street, 1867), ${ }^{62}$ and in Dunedin the idiosyncratic Oriental Hotel was built in 1863; architect unknown. ${ }^{63}$ In the gold fields Thomas Carter established the Acheron Accommodation House in 1863 on what was then the main route between Christchurch and Nelson. ${ }^{64}$ Of the 83 breweries built in the 46 years from 1835-81, that Geoffrey Thornton records in his New Zealand's Industrial Heritage, a large proportion of them (32) were built in the 1860s. The 1966 Encyclopaedia of

\footnotetext{
${ }^{58}$ Donovan Country Churches of New Zealand p 40.

${ }^{59}$ Kernohan Wellington's Old Buildings p 70.

${ }^{60}$ Kernohan Wellington's Old Buildings p 55.

${ }^{61}$ Thornton Cast in Concrete p 24.

62 Shaw Whitestone Oamaru pp 16,56-57.

${ }^{63}$ Stacpoole \& Beaven New Zealand Art p 22, pl 10

${ }^{64}$ McLean 100 Historic Places in New Zealand p 72.
}

New Zealand records that: "During the 1860s ... the widespread drunkenness, which was such a feature of pioneering life, found a response in the foundation of a large number of temperance societies. The New Zealand Independent Order of Rechabites, a total abstinence benefit society, and a Band of Hope Union were both founded in Auckland in 1863 ... [and d]uring the 1860s most provinces passed licensing ordinances."65

The 1860s was a period of changing building technology, materials and other regulations. Fires in particular caused the introduction of new regulations by local councils. The first Thistle Inn, Thorndon, for example was burnt down the same year it was built (1866). ${ }^{66} \mathrm{~A}$ Charles Tringham-designed church in Wellington (1868) was also destroyed by a fire in 1879. ${ }^{67}$ There was a major fire in Wellington in 1868, which prompted the Wellington City Council to propose by-laws to limit fire-risk. ${ }^{68}$ Buildings were made of a significant number of materials ranging from raup $\bar{o}^{69}$ to masonry, flammable materials in

\footnotetext{
65 "Prohibition: The Movement in New Zealand" n.p.

${ }^{66}$ Kernohan Wellington's Old Buildings p 55.

${ }^{67}$ Kernohan Wellington's Old Buildings pp 111-112.

${ }^{68}$ Kernohan Wellington's Old Buildings pp 68,70.

${ }^{69}$ Shaw New Zealand Architecture p 15.
} 
particular being targetted by regulation. Timber building was restricted in some town centres, and technological fashions phased out construction techniques such as wattle-anddaub. CE Dampier's Esk Head Homestead (1863) was built of a thick cob exterior walls, but the interior partitions were wattle-anddaub, ${ }^{70}$ and the last known house made of wattle-and-daub dates from 1869 (Jenkin's Cottage, Ōtaki). ${ }^{71}$ Corrugated iron was first manufactured in New Zealand in Dunedin in $1869 .{ }^{72}$

Masonry building appears to have been on the increase, with Knight and Wales noting an increase in the number of stonemasons from $1860-61,{ }^{73}$ and the discovery of Oamaru limestone as a material suitable for building in 1863. ${ }^{74}$ The Auckland Supreme Court (1866) was an important masonry building of the period ${ }^{75}$ with its intricately carved gargoyles (by Anton Teunberg) depicting "heads of prominent Maori figures and Pakeha

\footnotetext{
70 Shaw New Zealand Architecture p 20.

${ }^{71}$ Salmond Old New Zealand Houses p 36.

72 Salmond Old New Zealand Houses p 66.

${ }^{73}$ Knight \& Wales Buildings of Dunedin p 25.

${ }^{74}$ Knight \& Wales Buildings of Dunedin $\mathrm{p} 17$.

${ }^{75}$ Stacpoole William Mason p 85.
}

politicans for the building."76 The oldest extant concrete building also dates from the 1860s: the two storey house, built by John Gow in 1862 at Invermay, near Mosgiel, ${ }^{77}$ and one of the first stone buildings in Dunedin, Kilgour's building, was put out to tender in February $1860 .{ }^{78}$

Steam-driven machines were making $T \& G$ floorboards by the 1860s. ${ }^{79}$ Christian Toxward reportedly introduced rusticated board to New Zealand in the 1860s. ${ }^{80}$ The central internal gutter of the New Zealand villa also dates from this period, ${ }^{81}$ and timber was well established as the dominant building material for houses. ${ }^{82}$ According to Jeremy Salmond, "[b]y 1860 the small timber house had become established as the New Zealand vernacular dwelling, and from this little wooden cottage the forms of other ordinary New Zealand houses developed."83 Several buildings were prefabricated, perhaps most famously houses

${ }^{76}$ Shaw New Zealand Architecture p 33.

77 Thornton Cast in Concrete pp 23,25.

${ }_{78}^{78}$ Kight \& Wales Buildings of Dunedin p 26.

${ }^{79}$ Salmond Old New Zealand Houses pp 67, 89.

${ }^{80}$ Salmond Old New Zealand Houses p 115.

${ }^{81}$ Salmond Old New Zealand Houses p 121.

82 Shaw New Zealand Architecture p 45.

${ }^{83}$ Salmond Old New Zealand Houses p 60. c.f. Shaw New Zealand Architecture p 45. brought from England such as Hemming's Patent Improved Portable Houses of c1860, ${ }^{84}$ as Salmond notes: "[t]he Victorian vernacular in New Zealand was founded on a kitset of wooden parts, mass-produced by steampowered machines which began to arrive here in the late 1850s." 85 Other prefabs included Bill Clayton's Colonial Museum in Wellington, which was commissioned in 1865 and prefabricated in Dunedin. ${ }^{86}$ Minniesdale Chapel in Wharehini, Port Albert was also constructed of prefabricated parts, in this case from England. It opened in 29 December $1867 .{ }^{87}$

Cities were also subject to urban-scale technological advancements. New Zealand's first gasworks, the Dunedin Gaslight and Coke Company, was established in $1863,^{88}$ and the following year, in 1864, "Princes Street [in Dunedin] had pavements, kerbs, and gas lamps."89 Other cities followed, with coke gas being produced in "Christchurch in 1864,

${ }^{84}$ Salmond Old New Zealand Houses pp 27, 29.

85 Salmond Old New Zealand Houses p 90.

${ }^{86}$ Stacpoole William Mason p 87; Knight \& Wales Buildings of Dunedin pp 97-98.

${ }^{87}$ Donovan Country Churches of New Zealand p 16.

${ }^{88}$ Thornton New Zealand's Industrial Heritage p 180.

${ }^{89}$ Knight \& Wales Buildings of Dunedin $\mathrm{p} 32$. 
Auckland in 1868, and Wellington in 1871."90 New window types were added to residential buildings to both increase the amount of daylight inside, but to also take advantage of this new found nocturnal light source. Salmond also notes that: "'Sidelights" and "fanlights" were first added to the front door in the 1860s to brighten the hall, and to lend a little of the gaslight's glow to the street at night,"91 while Toomath records the new fashions for the Italianate style evident in window selection introduced in the 1860s: "round-arched window heads on double-hung sashes, often in pairs, beneath lowish, 30degree gables with open eaves lines." 92

Toomath has comprehensively documented the significant American influence on New Zealand architecture, particularly in the domestic realm. Examples of this include plan book designs such as those of Downing and Davis. ${ }^{93}$ Likewise Shaw notes the influence of American architect Andrew Jackson Downings' "Carpenter Gothic style, which reproduced Gothic stone tracery in wood, became popular in the USA during the

\footnotetext{
${ }^{90}$ Salmond Old New Zealand Houses p 148.

${ }^{91}$ Salmond Old New Zealand Houses p 133.

${ }^{92}$ Toomath Built in New Zealand p 94.

${ }_{93}$ Toomath Built in New Zealand p 62.
}

1850s and 1860s. It achieved popularity here too in the period when builders and their clients wished to move beyond the simple unadorned forms of the earliest colonial housing."94 Similarly Charles Eastlake's 1868 Hints in Household Taste was a fashionable leader in decorative practices in $\mathrm{New}$ Zealand. ${ }^{95}$ Many domestic buildings were designed during the period, many of which still survive. Examples include: Spinks Cottage, Wellington (William Spinks, 195463), ${ }^{96}$ Choat House, Puketona (c1860), ${ }^{97}$ Fyffe House, Kaikōura (c1860), ${ }^{98}$ Te Wahapū, near Russell (c.1860), ${ }^{99}$ Highwic, Epsom (1862), ${ }^{100}$ Invermay, near Mosgiel (John Gow, 1862), ${ }^{101}$ Alberton, Mt Albert (Allan Taylor, 1862), ${ }^{102}$

\footnotetext{
${ }^{94}$ Shaw New Zealand Architecture p 39.

${ }^{95}$ Salmond Old New Zealand Houses p 178; Toomath Built in New Zealand p 136.

${ }^{96}$ Kernohan Wellington's Old Buildings p 104.

${ }^{97}$ Salmond Old New Zealand Houses p 84.

${ }^{98}$ Fowler \& van de Voort The New Zealand House p 120.

${ }^{99}$ Salmond Old New Zealand Houses p 84.

${ }^{100}$ Hodgson Looking at the Architecture of New Zealand pp 16-17; Shaw New Zealand Architecture pp 39-40;

McCarthy "The Spirit of Christmas Past" pp 22-27;

Toomath Built in New Zealand p 62; Stacpoole "Auckland Houses" pp 98-99,104.

101 Thornton Cast in Concrete pp 23,25; "Invermay Agriculture Research Centre" n.p.

102 Shaw New Zealand Architecture p 41; Fowler \& van de Voort The New Zealand House p 26; Stacpoole "Auckland
}

Esk Head Homestead, Canterbury (Christopher Edward Dampier, 1863), ${ }^{103}$ Highlawn, Dunedin (William Mason, 1863), ${ }^{104}$ Ewelme Cottage, Parnell (1863-64), ${ }^{105}$ Bishopscourt or Selwyn Court, Parnell (Thatcher, 1863-66), ${ }^{106}$ Chew House (Millwood), Ngaio (John Chew c1865), ${ }^{107}$ the Mt Peel homestead (Frederick Stouts, 1865, built by JBA Acland), ${ }^{108}$ Dr Boor's house, 22 The Terrace, Wellington (Toxward, 1866), ${ }^{109}$ Yule House, Invercargill (1866), ${ }^{110}$ Te Makiri, Helensville (1866), ${ }^{111}$ Netherdale, Whanganui (1867), ${ }^{112}$ Oneida, Fordell, near Whanganui

Houses" pp 99-100,103.

${ }^{103}$ Shaw New Zealand Architecture p 20

104 Stacpoole William Mason p 77.

${ }^{105}$ Fowler \& van de Voort The New Zealand House pp 132 133; Stacpoole "Anglican Parnell" pp 93,94,97.

${ }^{106}$ Hodgson Looking at the Architecture of New Zealand pp 14-15; Fowler \& van de Voort The New Zealand House pp 24-25; Stacpoole \& Beaven New Zealand Art p 19, pl 7,

7A; Knight The Selwyn Churches of Auckland p 49; Shaw New Zealand Architecture p 27.

${ }^{107}$ Fowler \& van de Voort The New Zealand House p 100; "Chew House" n.p.

108 Fowler \& van de Voort The New Zealand House p 152. ${ }^{109}$ Kernohan Wellington's Old Buildings p 210; Arthur

"The Fine Art of Housing Craft" pp 114-119.

${ }^{110}$ Dear The Invercargill Book p 59.

111 Salmond Old New Zealand Houses p 84; Toomath Built in New Zealand p 62.

112 Salmond Old New Zealand Houses p 84. 
(George Frederick Allen, 1867-69), ${ }^{113}$ Fernhill, Dunedin (David Ross, 1867), ${ }^{114}$ Clendon House, Rawene (1868), ${ }^{115}$ and Jenkin's cottage, Ōtaki (1869). ${ }^{116}$

More significantly though, reflected in the huge number of publications in the area, was the building of religious buildings. Māori and the Anglican church collaborated in the building of several buildings with plain gothic exteriors and rich whakairo inside, perhaps culminating in the Manutuke church (1863). ${ }^{117}$ The development of the Te Kooti wharenui as Ringatū religious buildings, and Frederick Thatcher's collaboration with Bishop Selwyn were significant developments in New Zealand religious architecture. Selwyn churches built at this time, many designed or influenced by Thatcher, included: St Bride's, Mauku (Arthur Guyon Purchase, 1860), ${ }^{118}$ St

113 Shaw New Zealand Architecture pp 40-41; Fowler \& van de Voort The New Zealand House p 84; Toomath Built in New Zealand pp 63-64.

114 Fowler \& van de Voort The New Zealand House p 163 "Dunedin Club" n.p.; Stacpoole William Mason p 77.

115 Salmond Old New Zealand Houses p 84.

116 Salmond Old New Zealand Houses p 36.

117 Brown Maori Architecture p 48.

118 Shaw New Zealand Architecture p 27; Knight The

Selwyn Churches of Auckland pp 68-70; Stacpoole, John William Mason p 49.
John the Baptist, Northcote (1860), ${ }^{119}$ St Mark's, Remuera (1860), ${ }^{120}$ St Mary's, Parnell (1860), ${ }^{121}$ St John's Drury (1861), ${ }^{122}$ Wairoa Episcopalian Church, Clevedon (1861), ${ }^{123}$ Christ Church, Papakura (1862), 124 Holy Trinity, Ōtāhuhu, (1863), 125 St Sepulchre's, Symonds Street (1865-91), ${ }^{126}$ St Andrew's, Epsom (Reader Wood and Edward Rumsey, 1867), ${ }^{127}$ and St Peter's in the Forest, Bombay (Edward Rumsey, 1867). ${ }^{128}$

Churches designed in the 1860s included a range from the monumental cathedral to the minute chapel, and across all denominational types: Christchurch Cathedral (Gilbert Scott, completed 1904) $)^{129}$ - its concrete foundations

\footnotetext{
${ }^{119}$ Knight The Selwyn Churches of Auckland pp 62-64. ${ }^{120}$ Knight The Selwyn Churches of Auckland p 38.

${ }^{121}$ Knight The Selwyn Churches of Auckland p 46. 122 Knight The Selwyn Churches of Auckland pp 71-73,7677.

${ }^{123}$ Knight The Selwyn Churches of Auckland pp 71-73,7879; Donovan Country Churches of New Zealand p 21.

${ }^{124}$ Knight The Selwyn Churches of Auckland pp 73-75.

${ }^{125}$ Knight The Selwyn Churches of Auckland p 32.

${ }^{126}$ Knight The Selwyn Churches of Auckland pp 60-61.

${ }^{127}$ Knight The Selwyn Churches of Auckland pp 24,39-40.

${ }^{128}$ Knight The Selwyn Churches of Auckland pp 80-82.

${ }^{129}$ Hodgson Looking at the Architecture of New Zealand pp 12-13; Shaw New Zealand Architecture p 31; Fowler Buildings of New Zealanders p 185; Shaw Whitestone Oamaru p 12.
}

used 2,000 barrels of cement, ${ }^{130}$ Dunedin's First Church (Robert Lawson, opened 1873), ${ }^{131}$ Knox Church, Great King Street, Dunedin (William Langslands, 1859-60), ${ }^{132}$ St Augustine's, Clarkville (1860), ${ }^{133}$ St Cuthbert's, Governors Bay (George Mallinson, 1860c1862), ${ }^{134}$ St Mary's Church (Parnell, 1860), ${ }^{135}$ Oruaiti Octagonal Chapel, Mongōnui Harbour (1861), ${ }^{136}$ All Saints, Howick (1847, 1862), ${ }^{137}$ Wainui Early Settlers' Church (1862), ${ }^{138}$ Wheriko Whare Karakia, Parewanui (1862), ${ }^{139}$ Pukekohe East Presbyterian (1863), ${ }^{140}$ St Anne's, Pleasant Valley (1863), ${ }^{141}$ St Mary's, Meeanee (1863), ${ }^{142}$ St Paul's Church, Octagon,

130 Thornton Cast in Concrete p 24

${ }^{131}$ Hodgson Looking at the Architecture of New Zealand pp 12-13; Stacpoole \& Beaven New Zealand Art pp 11,28-29, pl 16,17; Knight \& Wales Buildings of Dunedin pp 128135; Fowler Buildings of New Zealanders p 185; Shaw Whitestone Oamaru pp 15-16.

${ }^{132}$ Knight \& Wales Buildings of Dunedin pp 124-125.

${ }^{133}$ Donovan Country Churches of New Zealand p 82.

${ }^{134}$ Donovan Country Churches of New Zealand p 83.

135 Kernohan Wellington's Old Buildings pp 52-53.

136 Donovan Country Churches of New Zealand p 16.

${ }^{137}$ Fowler Buildings of New Zealanders p 182.

${ }_{138}$ Donovan Country Churches of New Zealand $\mathrm{p} 18$.

${ }^{139}$ Donovan Country Churches of New Zealand p 69.

${ }^{140}$ Donovan Country Churches of New Zealand p 22

${ }^{141}$ Donovan Country Churches of New Zealand p 94.

${ }_{142}$ Donovan Country Churches of New Zealand p 43. 
Dunedin (Charles Abbott, 1863), ${ }^{143}$ Wesleyan Church, Dunedin (George Greenfield, 1863), ${ }^{144}$ Hiona/St Stephen the Martyr, Ōpōtiki (1864), ${ }^{145}$ St Mary's, Palmerston (1864-72), ${ }^{146}$ St Peter's, Caversham (1864), ${ }^{147}$ All Saints Church, North Dunedin (Clayton and Mason, 1865), ${ }^{148}$ Church of the Holy Trinity (1865), ${ }^{149}$ St Luke's, Oamaru (Edward Rumsey, 18651912), ${ }^{150}$ St Patrick's, Akaroa (Maxwell Bury, 1865), ${ }^{151}$ St Paul's Presbyterian Church, Oamaru (Mason and Clayton, 1865), ${ }^{152} \mathrm{St}$ Andrew's Church, Lambton Quay, Wellington (Toxward, 1866), 153 St Peter's, Whanganui (1866), ${ }^{154}$ St Michael's, Waimea West (Thomas Brunner, 1867), ${ }^{155}$ Church of the Holy

\footnotetext{
${ }^{143}$ Knight \& Wales Buildings of Dunedin pp 68-70.

${ }^{144}$ Knight \& Wales Buildings of Dunedin $\mathrm{p} 112$.

${ }^{145}$ Donovan Country Churches of New Zealand p 34.

146 Donovan Country Churches of New Zealand p 100.

147 Stacpoole, John William Mason p 86.

148 Shaw New Zealand Architecture p 35; Knight \& Wales Buildings of Dunedin pp 97-99; Stacpoole, John William

Mason p 86; Martin, Lewis Built for Us p 13.

${ }^{149}$ Knight The Selwyn Churches of Auckland p 62.

${ }^{150}$ Shaw Whitestone Oamaru pp 12, 75.

${ }^{151}$ Donovan Country Churches of New Zealand p 86-87.

152 Shaw Whitestone Oamaru p 12; Stacpoole, John William Mason p 86.

${ }^{153}$ Kernohan Wellington's Old Buildings p 22.

${ }^{154}$ Donovan Country Churches of New Zealand p 58.

${ }^{155}$ Donovan Country Churches of New Zealand p 125
}

Innocents, Mount Peel (1868-c1869), ${ }^{156}$ Community Church, Pukehiki (Walter Riddell, 1868), ${ }^{157}$ St Thomas', Maketu (1868), ${ }^{158}$ East Tākaka Church (1868), ${ }^{159}$ and St Mary's, Stirling, nr Balclutha (1869). ${ }^{160}$

Less well documented are religious buildings from non-Christian religions. William Clayton's Moray Pl West Synagogue (1864$65)^{161}$ being one of the few.

The 1860s also saw the first daily newspaper founded - the Otago Daily Times. Less frequent newspapers had begun with the arrival of the New Zealand Company in the 1839. Other technologies of communication (the electric telegraph line in 1862, to support Grey's Waikato wars; the first railway line in 1863, from Christchurch to Ferrymead; and the laying of the Cook Strait submarine telegraph cable in 1865), followed. ${ }^{162} \mathrm{New}$ Zealand's first railway station was built in

${ }^{156}$ Donovan Country Churches of New Zealand p 93. 157 Donovan Country Churches of New Zealand p 103. 158 Donovan Country Churches of New Zealand $\mathrm{p} 32$. 159 Donovan Country Churches of New Zealand p 124. 160 Donovan Country Churches of New Zealand p 106. ${ }^{161}$ Knight \& Wales Buildings of Dunedin pp 97-98; Stacpoole, John William Mason p 87.

162 Smith A Concise History of New Zealand p 71; Keith \& McRobie Historical Dictionary of New Zealand p 5.
1864 - in Invercargill, with railway line between Lyttelton port and Christchurch, and between Invercargill and Bluff, both being constructed in 1867. ${ }^{163}$ The Invercargill-Bluff line was built of wooden rails and reputedly bankrupted the Southland Province. ${ }^{164}$

Provincial and Colonial government provided various instances of building, including: the Government wharf and bonded store, Wellington (1862-63), ${ }^{165}$ Auckland Supreme Court (Edward Rumsey, 1864), ${ }^{166}$ and the Dunedin Court House and Gaol, Bell Hill (1862). ${ }^{167}$ While the provinces of New Zealand were first established in 1841, it was not until 1852 that the six most enduring provinces were established (those of: Auckland, New Plymouth, Wellington, Nelson, Canterbury and Otago). The creation of Hawke's Bay and Marlborough occurred in the 1850s, but the

${ }^{163}$ Dear The Invercargill Book p 54; Fowler Buildings of New Zealanders p 24; McLean 100 Historic Places in New Zealand p 79.

164 Fowler Buildings of New Zealanders p 24.

165 Kernohan Wellington's Old Buildings pp 160-161.

166 Hodgson Looking at the Architecture of New Zealand pp 10-11; Stacpoole \& Beaven New Zealand Art pp 11,27, pl. 15,15A; Shaw New Zealand Architecture pp 32-33; Fowler Buildings of New Zealanders p 75; Evans "The Supreme

Court House, Auckland" pp 106-111.

${ }^{167}$ Knight \& Wales Buildings of Dunedin p 28. 
1860s was the decade of the Province of Southland's existence (1861-69). ${ }^{168}$ The decade was also a period when architectural infrastructure to support the Provinces. Mountfort designed the renowned Canterbury Provincial Council Chambers (1858-65), ${ }^{169}$ and Max Bury the Elizabethan Nelson Provincial Building (1859-61). ${ }^{170}$ Other architects also forger career in this civil service. WB Armson was an assistant architect for the Otago Provincial Government $(1862-65),{ }^{171}$ while Charles Robert Swyer (Armson's boss) was the Provincial Engineer from 1862. ${ }^{172}$ In 1969 William H Clayton was appointed Colonial Architect. ${ }^{173}$ His work included: the Colonial Museum (Clayton, 1865), ${ }^{174}$ and Government House, Wellington

168 Keith \& McRobie Historical Dictionary of New Zealand pp 4,6 .

${ }^{169}$ Hodgson Looking at the Architecture of New Zealand pp 4-5; Stacpoole \& Beaven New Zealand Art pp 11,25, pl. 13; Shaw New Zealand Architecture p 30; Fowler Buildings of New Zealanders p 104.

170 Shaw New Zealand Architecture p 36.

171 "A colonial architect rediscovered" pp 24-25; Knight \&

Wales Buildings of Dunedin $\mathrm{p} 34$.

172 Knight \& Wales Buildings of Dunedin p 34.

${ }^{173}$ Kernohan Wellington's Old Buildings p 22; Hodgson

Looking at the Architecture of New Zealand p 6; Stacpoole \& Beaven New Zealand Art p 11; Shaw New Zealand

Architecture p 36; Martin Built for Us pp 10,14.

${ }^{174}$ Kernohan Wellington's Old Buildings p 22.
(Clayton, c1868-71). ${ }^{175}$ The decade ended with Julius Vogel, the Colonial Treasurer, successfully proposing huge government debt to fund an extensive programme of public works. ${ }^{176}$ For architecture, the 1860 s ended on a high and on borrowed money.

175 Kernohan Wellington's Old Buildings p 22; Hodgson Looking at the Architecture of New Zealand p 7; Martin Built for Us $\mathrm{p} 10$.

${ }^{176}$ Keith \& McRobie Historical Dictionary of New Zealand $\mathrm{p}$ 


\section{REFERENCES}

"A colonial architect rediscovered" Home and Building (February/March 1984):24-25.

Arthur, Mary-Alice "The Fine Art of Housing Craft" Home and Building (April/May 1986):114-119.

Brown, Deidre Māori Architecture: from fale to wharenui and beyond North Shore, NZ: Penguin Group, 2009.

"Chew House: 19 Ottawa Road, Ngaio, Wellington [Register entry]" New Zealand Historic Places Trust http://www.historic.org.nz/TheRegister/RegisterSearch/RegisterResul ts.aspx?RID $=1348$

Dear, Lynley The Invercargill Book Invercargill: Morepork Press, 2005.

"Department stores and shopping malls: The rise of department stores" Te Ara http://www.teara.govt.nz/en/department-stores-andshopping-malls/1

Donovan, Don Country Churches of New Zealand Auckland: New Holland Publishers, 2002.

"Dunedin Club: 33 Melville Street, Fernhill, Dunedin [Register entry]" New Zealand Historic Places Trust

http://www.historic.org.nz/TheRegister/RegisterSearch/RegisterResul ts.aspx?RID=2151

England, Bevis "The Story of Mansion House" Home and Building (August/September 1986):70.

Evans, Enid "The Supreme Court House, Auckland" Historic Buildings of New Zealand: North Island Northcote, Auckland: Cassell Ltd, 1979:106111.

Fowler, Michael Buildings of New Zealanders Auckland: Lansdownes Press, 1984.

Fowler, Michael and Robert van de Voort The New Zealand House Parnell, Auckland: Lansdowne Press, 1983.
Hodgson, Terence Looking at the Architecture of New Zealand Wellington: Grantham House, 1990.

"Invermay Agriculture Research Centre: Factory Road, Wingatui [Register entry]" New Zealand Historic Places Trust

http://www.historic.org.nz/TheRegister/RegisterSearch/RegisterResul ts.aspx?RID=2350

Jackson, Keith and Alan McRobie Historical Dictionary of New Zealand Auckland: Longman, 1996.

Kernohan, David Wellington's Old Buildings Wellington: Victoria University Press, 1994.

Knight, C.R. The Selwyn Churches of Auckland Wellington: A.H. \& A.W. Reed, 1972.

Knight, Hardwick and Niel Wales Buildings of Dunedin: an illustrated guide to New Zealand's Victorian city Dunedin: John McIndoe, 1988.

McCarthy, Lynne "The Spirit of Christmas Past" Home and Building (December 1985/January 1986):22-27.

McLean, Gavin 100 Historic Places in New Zealand Auckland: Hodder Moa Beckett, 2002.

Martin, Lewis Built for Us: The Work of Government and Colonial Architects 1860s to 1960s Dunedin: University of Otago Press, 2004.

Neich, Roger Carved Histories: Rotorua Ngati Tarawhai Woodcarving Auckland: Auckland University Press, 2001.

"Ohaeawai - Northern War" New Zealand History Online http://www.nzhistory.net.nz/war/northern-war/ohaeawai

"Prohibition: The Movement in New Zealand" An Encyclopaedia of New Zealand 1966 http://www.teara.govt.nz/en/1966/prohibition/1

Salmond, Jeremy Old New Zealand Houses 1800-1940 Auckland: Reed Methuen, 1987; first published 1986.

Shaw, Peter New Zealand Architecture: from Polynesian beginnings to 1990 
Auckland, N.Z.: Hodder \& Stoughton, 1991.

Shaw, Peter Whitestone Oamaru: A Victorian Architectural Heritage Nelson: Craig Potton, 1995.

Smith, Philippa Mein A Concise History of New Zealand Melbourne: Cambridge University Press, 2005.

Stacpoole, John "Anglican Parnell" Historic Buildings of New Zealand: North Island Northcote, Auckland: Cassell Ltd, 1979:93,94,97.

Stacpoole, John "Auckland Houses" Historic Buildings of New Zealand: North Island Northcote, Auckland: Cassell Ltd, 1979:98-99,104.

Stacpoole, John William Mason: The First New Zealand Architect Auckland: Auckland University Press, 1971.

Stacpoole, John and Peter Beaven New Zealand Art: architecture 1820-1970 Wellington: A.H. \& A.W. Reed, 1972.

Thornton, Geoffrey Cast in Concrete: Concrete construction in New Zealand 1850-1939 Birkenhead, Auckland: Reed Books, 1996.

Thornton, Geoffrey C. New Zealand's Industrial Heritage Wellington: A.H. \& A.W. Reed Ltd, 1982.

Toomath, William Built in New Zealand: The Houses We Live In Auckland: HarperCollinsPublishers (NZ) Ltd, 1996.

"Towering Inferno" Home and Building (February/March 1987):137-139. 